OPEN ACCESS

Edited by:

Zhihua Wang,

Zhejiang University, China

Reviewed by:

Yu Wang,

Wuhan University of Technology,

China

Lei Zhou,

Harbin Institute of Technology,

Shenzhen, China

Jinhua Wang,

X'an Jiaotong University, China

*Correspondence:

Xing $\mathrm{Li}$

lixing@ms.giec.ac.cn

inspirationlee@hotmail.com

Specialty section:

This article was submitted to Advanced Clean Fuel Technologies,

a section of the journal

Frontiers in Energy Research

Received: 03 January 2022

Accepted: 24 January 2022

Published: 17 February 2022

Citation:

Zhang F, Li X, Xie S, Wang J and Wang $X$ (2022) Experimental and Numerical Study on the Combustion Characteristics of a Laminar NonPremixed Methane Jet Flame in Oxygen/Carbon Dioxide Coflow. Front. Energy Res. 10:847947. doi: 10.3389/fenrg.2022.847947

\section{Experimental and Numerical Study on} the Combustion Characteristics of a Laminar Non-Premixed Methane Jet Flame in Oxygen/Carbon Dioxide Coflow

\author{
Fan Zhang ${ }^{1}$, Xing $\mathrm{Li}^{2,3,4 *}$, Shengrong Xie ${ }^{2,5}$, Junxiong Wang ${ }^{2}$ and Xiaohan Wang ${ }^{2}$
}

${ }^{1}$ School of Mechanical and Electric Engineering, Guangzhou University, Guangzhou, China, ${ }^{2}$ Guangzhou Institute of Energy Conversion, Chinese Academy of Sciences, Guangzhou, China, ${ }^{3}$ Dalian National Laboratory for Clean Energy, Dalian, China, ${ }^{4}$ Department of Energy and Mechanical Engineering, Hunan Institute of Humanities, Science and Technology, Loudi, China, ${ }^{5}$ University of Chinese Academy of Sciences, Beijing, China

The combustion characteristics of laminar non-premixed $\mathrm{CH}_{4}$ jet flame in an $\mathrm{O}_{2} / \mathrm{CO}_{2}$ coflows with different oxygen mole fractions were studied experimentally. The flame heights at different oxygen concentrations and fuel jet velocity were obtained. The experimental observation shows that the luminosity of the $\mathrm{CH}_{4}$ jet flame in $\mathrm{O}_{2} / \mathrm{CO}_{2}$ coflow is different from that of the flame in air stream. A two-dimensional numerical study of a laminar non-premixed $\mathrm{CH}_{4}$ jet flame in the $\mathrm{O}_{2} / \mathrm{CO}_{2}$ coflow with the $\mathrm{O}_{2}$ mole fraction of 0.35 was conducted to analyze the effects of $\mathrm{CO}_{2}$ dilution on the flame. The distribution of $\mathrm{OH}$ radicals in the flame was measured experimentally using planar laserinduced fluorescence (PLIF) to validate the computational method adopted in this work, and the computational and experimental results of the $\mathrm{OH}$ distributions showed good consistency at various fuel flow velocities. Three artificial species were created in the numerical experiment to analyze the effects of the chemical reactions, third-body collisions, and transport properties of $\mathrm{CO}_{2}$ on the height, width, and temperature distribution of the flame. The results showed that $\mathrm{CO}_{2}$ participation in chemical reactions exerts significant effects on the flame. However, the influences of the third-body effects and transport properties of $\mathrm{CO}_{2}$ on the jet flame are unremarkable. The global reaction pathways and distributions of important species in the laminar non-premixed $\mathrm{CH}_{4}$ jet flame were analyzed in detail to investigate the influence mechanisms of $\mathrm{CO}_{2}$ on the flame height and temperature. The entire flame can be divided into two oxidation parts, which separated by the boundary of the $\mathrm{HCCO}$. The $\mathrm{H}, \mathrm{O}$, and $\mathrm{OH}$ concentrations and distributions in different parts of the flame were influenced by $\mathrm{CO}_{2}$ dilution, resulting in different flame heights and temperature distributions.

Keywords: non-premixed laminar jet flame, $\mathrm{O}_{2} / \mathrm{CO}_{2}$ coflow, chemical effect, third-body effect, transport property 


\section{INTRODUCTION}

The reduction of $\mathrm{CO}_{2}$ emissions during fossil fuel utilization is an important task for human society. The injection of purified $\mathrm{CO}_{2}$ from flue gas into underground reservoirs is believed to help achieve this goal (Buhre et al., 2005; Wall, 2007). However, $\mathrm{CO}_{2}$ rich flue gas is required to increase the efficiency and economy during carbon capture and storage. Several new advanced combustion technologies that use $\mathrm{O}_{2} / \mathrm{CO}_{2}$ as an oxidizer, such as oxy-fuel combustion technology (Buhre et al., 2005; Wall, 2007; Hjärtstam et al., 2009; Rathnam et al., 2009; Scheffknecht et al., 2011; Taniguchi et al., 2011; Chen et al., 2012; Dhaneswar and Pisupati, 2012; Luo et al., 2015; Moroń and Rybak, 2015; Liu et al., 2016; Ge et al., 2017; Seddighi, 2017; Menage et al., 2018; Zhang et al., 2018), moderate or intense low-oxygen dilution (MILD) oxy-combustion (Li et al., 2013; Tu et al., 2015; Mardani and FazlollahiGhomshi, 2016; Mao et al., 2017; Gładysz et al., 2018), gaseous fuel-fired oxy-fuel combustion technology (Yin et al., 2011; Seepana and Jayanti, 2012a; Seepana and Jayanti, 2012b; Oh et al., 2013a; Oh et al., 2013b; Oh and Noh, 2013; Oh and Noh, 2014; Giménez-López et al., 2015; Oh and Noh, 2015; Oh and Hong, 2016; Bürkle et al., 2018), and high-temperature oxygen combustion technology (Li et al., 2014; Li et al., 2015; Li et al., 2016), have been developed to meet this requirement. However, many other challenges must be solved before these combustion technologies can be widely adopted in the industry, since the differences in the physical properties and chemical characteristics of $\mathrm{CO}_{2}$ and $\mathrm{N}_{2}$ can lead to important distinctions in flame structure. More information on the combustion characteristics of different fuels in various $\mathrm{O}_{2} / \mathrm{CO}_{2}$ environments must be obtained for the development of new combustion approaches.

Experimental and numerical studies on the fundamental combustion characteristics of $\mathrm{O}_{2} / \mathrm{CO}_{2}$-fired flames have been conducted previously. The effect of $\mathrm{CO}_{2}$ on the freepropagation speed of laminar premixed $\mathrm{CH}_{4} / \mathrm{O}_{2} / \mathrm{CO}_{2}$ flames was investigated numerically (Liu et al., 2003). The speeds of laminar $\mathrm{CH}_{4} / \mathrm{O}_{2} / \mathrm{CO}_{2}$ flames at different equivalence ratios and pressures were measured and computed (Xie et al., 2013). The $\mathrm{CH}_{4}$ oxidation under $\mathrm{CO}_{2}$-rich conditions has also been investigated using an atmospheric pressure flow reactor (Glarborg and Bentzen, 2008). The effects of environmental pressure (Maruta et al., 2007) and oxidizer temperature (Li et al., 2014) on the stretch extinction characteristics of $\mathrm{CH}_{4}$ / $\mathrm{CO}_{2}$ versus $\mathrm{O}_{2} / \mathrm{CO}_{2}$ counterflow non-premixed flames have been studied through experiments and numerical computations. The ignition temperature of a stoichiometric $\mathrm{CH}_{4} / \mathrm{O}_{2} / \mathrm{CO}_{2}$ mixture was examined by using a micro flow reactor with a controlled temperature profile (Li et al., 2015). The fundamental studies (Liu et al., 2003; Maruta et al., 2007; Glarborg and Bentzen, 2008; Xie et al., 2013; Li et al., 2014; Li et al., 2015; Li et al., 2016) show that $\mathrm{CO}_{2}$ exerts an inhibitory effect on flames. Consequently, a higher oxygen concentration is recommended for the $\mathrm{O}_{2} / \mathrm{CO}_{2}$-fired flames to achieve a comparable combustion characteristics as the air flames.

The previous fundamental studies have provided an essential understanding of flames in $\mathrm{O}_{2} / \mathrm{CO}_{2}$ environments (Liu et al.,

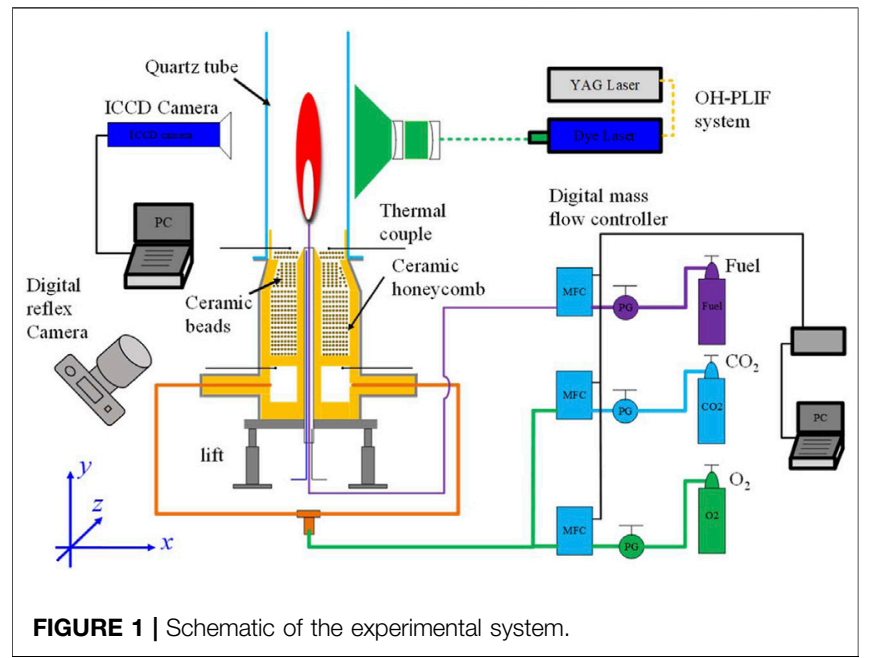

2003; Maruta et al., 2007; Glarborg and Bentzen, 2008; Xie et al., 2013; Li et al., 2014; Li et al., 2015; Li et al., 2016). However, the three-dimensional structures of flames in $\mathrm{O}_{2} / \mathrm{CO}_{2}$, which are important for the development of industrial burner, deserves more attention. The combustion characteristics of turbulent premixed $\mathrm{CH}_{4} /$ air/ $/ \mathrm{CO}_{2}$ and $\mathrm{CO} / \mathrm{H}_{2} / \mathrm{CO}_{2} / \mathrm{O}_{2}$ flames was investigated experimentally (Kobayashi et al., 2007; Kobayashi et al., 2009; Wang et al., 2013). And it was observed that local wrinkled structures become sharp and propagate deeply into the burned mixture with addition of $\mathrm{CO}_{2}$. It was also proposed that $\mathrm{CO}_{2}$ addition is effective for restraining combustion oscillation (Kobayashi et al., 2007). Experimental studies of the swirlstabilized turbulent $\mathrm{CH}_{4} /$ air and $\mathrm{CH}_{4} / \mathrm{O}_{2} / \mathrm{CO}_{2}$ flames show that the average length of air flames is longer than that of oxy-flames. Moreover, it was found that one-dimensional laminar flame properties could not be used to explain the intense burning of turbulent oxy-flames (Watanabe et al., 2016).

Recently, the influences of $\mathrm{CO}_{2}$ on the combustion characteristics of multidimensional flames has been studied in detail. The physical and chemical effects of $\mathrm{CO}_{2}$ dilution on a $\mathrm{CH}_{4} / \mathrm{H}_{2}$ jet flame in the MILD oxy-combustion regime have been investigated using two-dimensional numerical computations with a detailed kinetic mechanism (Tu et al., 2016; Tu et al., 2017). It was found that the chemical effects of $\mathrm{CO}_{2}$ play a comparable role in the suppression of temperature rise to the physical effects (Tu et al., 2016). The influences of $\mathrm{CO}_{2}$ dilution on the shape and structure of laminar $\mathrm{CO} / \mathrm{H}_{2}$ diffusion flames in an $\mathrm{O}_{2} / \mathrm{N}_{2} / \mathrm{CO}_{2}$ coflow was examined (Xu et al., 2017), and the chemical effects of the thermal and transport properties of $\mathrm{CO}_{2}$ on the flames were discussed in detail. The previous numerical studies provide important information on the effects of $\mathrm{CO}_{2}$ under MILD (Tu et al., 2016; Tu et al., 2017) and syngas (Xu et al., 2017) combustion regimes. However, the effects of $\mathrm{CO}_{2}$ on the flame shape and temperature distribution of gaseous-fuel-fired flames in an $\mathrm{O}_{2} / \mathrm{CO}_{2}$ environment with a high $\mathrm{O}_{2}$ concentration needs special attention and was not clarified.

The target of the present work is to study on the combustion characteristics of laminar non-premixed methane jet flames in oxygen/carbon dioxide coflows. The laminar flame heights at 
different oxygen concentrations were measured by experiments. The $\mathrm{OH}$ distributions of typical laminar methane jet flames in a $\mathrm{O}_{2} / \mathrm{CO}_{2}$ coflow were measured by OH-PLIF technique. Twodimensional numerical computations with a detailed kinetic mechanism were conducted, and three artificial species modified from $\mathrm{CO}_{2}$ were employed in the numerical experiment to clarify the effects of $\mathrm{CO}_{2}$. The influences through the chemical reactions, third-body collisions, and transport properties of $\mathrm{CO}_{2}$ on the combustion characteristics of a laminar non-premixed $\mathrm{CH}_{4}$ jet flame in an $\mathrm{O}_{2} / \mathrm{CO}_{2}$ environment with a high $\mathrm{O}_{2}$ concentration was distinguished in detail.

\section{EXPERIMENT}

\section{Experimental Setup and Method}

Figure 1 shows a schematic diagram of the experimental system. The jet-flame experimental apparatus includes three parts, namely, a quartz tube, a fuel tube, and a stainless-steel chamber. The length and height of the rectangular quartz tube are 10 and $60 \mathrm{~cm}$, respectively, and the wall thickness is $4 \mathrm{~mm}$. The fuel stream was supplied through a stainless-steel tube with an inner diameter $(d)$ of $1 \mathrm{~mm}$ and a length of $15 \mathrm{~cm}$. The fuel tube was installed at the center of a rectangular quartz tube. The rectangular quartz tube and the stainless-steel chamber were connected together, and a ceramic honeycomb (diameter, $12 \mathrm{~cm}$; height, $10 \mathrm{~cm}$ ) and ceramic beads (diameter, $2 \mathrm{~mm}$ ) were arranged in the stainless-steel chamber to achieve a uniform coflow velocity. A well-mixed $\mathrm{O}_{2} / \mathrm{CO}_{2}$ stream was fed into the rectangular quartz tube from the bottom of the chamber. Three MKS digital mass flow controllers were employed to control the volumetric flow rates of gases, and a wet gas meter (Shinagawa, W-NK-2) was used to calibrate the digital mass flow controllers. The rectangular quartz tube was adopted in the experiment because it is convenient for optical measurements. In addition, the similarity of non-premixed laminar $\mathrm{CH}_{4}$ jet flames in a circular tube with an inner diameter of $9.2 \mathrm{~cm}$ to those in a rectangular quartz tube has been confirmed by preliminary experiment. The laminar $\mathrm{CH}_{4}$ jet flames in $\mathrm{O}_{2} /$ $\mathrm{CO}_{2}$ colfows with different oxygen mole fractions $\left(X_{\mathrm{O} 2}=0.30\right.$, 0.35 and 0.40 ) were tested by the present experimental system.

A single-lens reflex digital camera (Nikon D-610, f/4) was fixed in front of the flame to record the flame images. The ISO and exposure time were set as 1,250 and $1 / 40 \mathrm{~s}$, respectively. The qualitative distribution of $\mathrm{OH}$ radicals in laminar non-premixed $\mathrm{CH}_{4}$ jet flames in an $\mathrm{O}_{2} / \mathrm{CO}_{2}$ coflow was measured using the $\mathrm{OH}$ PLIF technique. The experimental apparatus was fixed on a lifter with a scale which can adjust the position of the flame. Consequently, the $\mathrm{OH}$ distribution of the different parts of the flame can be measured. The distribution of $\mathrm{OH}$ radicals at the center plane of the flame was measured by the OH-PLIF system. A beam with a wavelength of $355 \mathrm{~nm}$ was provided by a Nd:YAG laser (Quanta-Ray Pro-230). This beam was then transformed into a new laser beam by a dye laser (Sirah PSCAN-G-30) to excite the $\mathrm{OH}$ radicals in the flame. The wavelength of the dye laser beam was around $283.565 \mathrm{~nm}$ for the present OH-PLIF

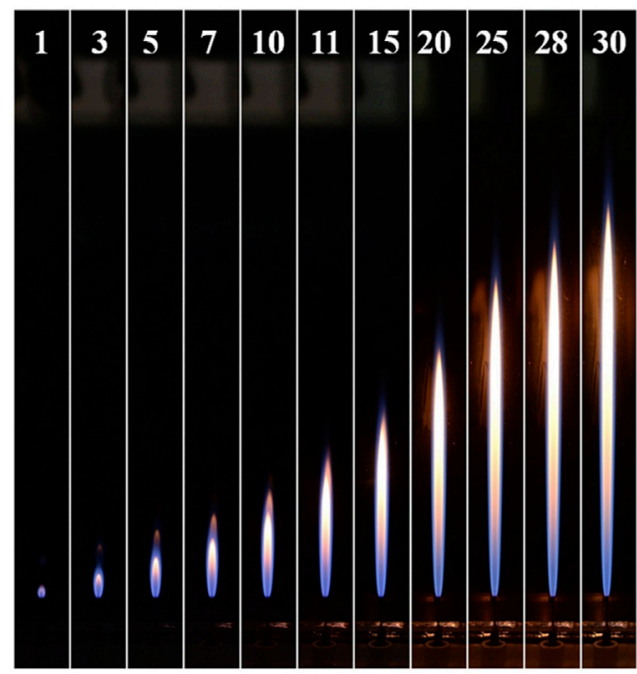

FIGURE 2 | The images of $\mathrm{CH}_{4}$-jet-flames in $\mathrm{O}_{2} / \mathrm{CO}_{2}$ coflows with an oxygen mole fraction of 0.35 . (The number on the top denotes the corresponding fuel flow velocity in the unit of $\mathrm{m} / \mathrm{s}$ ).

system. And the height of the laser sheet was about $40 \mathrm{~mm}$ and the thickness was less than $100 \mu \mathrm{m}$ at the location of the flame. An ICCD camera (LAVISION VC-IRO and VC-Imager Pro X 4M) with an $\mathrm{OH}$ filter was used to obtain the $\mathrm{OH}$ image of the flame. The finest pixel resolution of the ICCD camera at the flame position was approximately $50 \mu \mathrm{m}$. A detailed description of the $\mathrm{OH}-\mathrm{PLIF}$ system and the selected wavelength is provided elsewhere (Li et al., 2017). Raw OH-PLIF images were directly used for qualitative comparison with the numerical results because the measured $\mathrm{OH}$ intensity is proportional to the computational $\mathrm{OH}$ molar concentration within a $10 \%$ error (Yamamoto et al., 2009). The OH-PLIF results at each fuel flow velocity were averaged from every $100 \mathrm{OH}$-PLIF images. As the length of the laser sheet at the location of the flame was approximately $40 \mathrm{~mm}$, which cannot cover the overall scope of the flame, the $\mathrm{OH}$ distributions in different parts of the flame were measured by adjusting the height of the experimental apparatus. The overall $\mathrm{OH}$ distribution of a jet flame was assembled from the $\mathrm{OH}$ distributions at different parts of the flame.

\section{Experimental Results}

The flame height and width which are determined by oxygen concentration and fuel flow rate are important parameter for the design of the industrial burner. Consequently, the laminar $\mathrm{CH}_{4}$ jet flames in $\mathrm{O}_{2} / \mathrm{CO}_{2}$ coflows with oxygen mole fractions $\left(\mathrm{X}_{\mathrm{O} 2}\right)$ of $0.30,0.35$ and 0.40 were studied experimentally. The coflow velocity was kept at $0.1 \mathrm{~m} / \mathrm{s}$ for different cases. The laminar $\mathrm{CH}_{4}$ jet flames in the air coflow were also tested for the comparison. The images of $\mathrm{CH}_{4}$ laminar jet flames in the $\mathrm{O}_{2} /$ $\mathrm{CO}_{2}$ coflow $\left(X_{\mathrm{O} 2}=0.35\right)$ with different fuel jet velocities are shown in Figure 2. It can be seen that the flame height of the laminar $\mathrm{CH}_{4}$ jet flame increase linearly with the fuel velocity when the $\mathrm{O}_{2} / \mathrm{CO}_{2}$ is used as the oxidizer. 


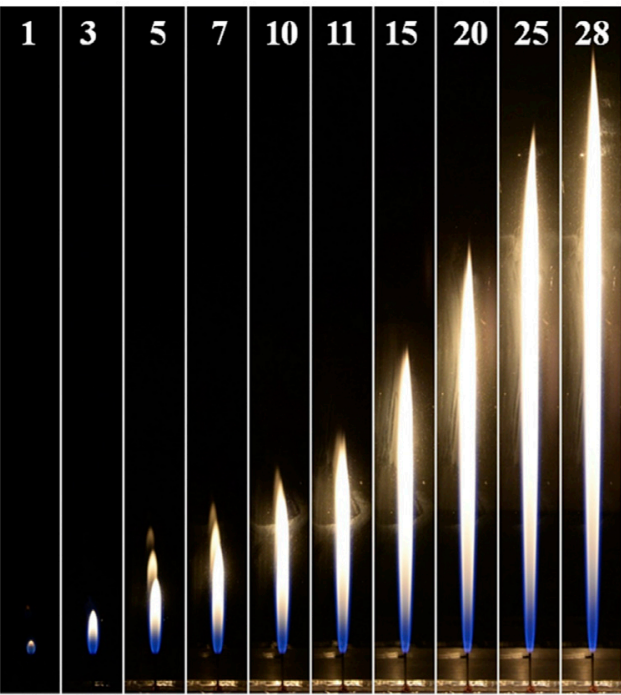

FIGURE 3 | The images of $\mathrm{CH}_{4}$-jet-flames in air coflow. (The number on the top denotes the corresponding fuel flow velocity in the unit of $\mathrm{m} / \mathrm{s}$ ).

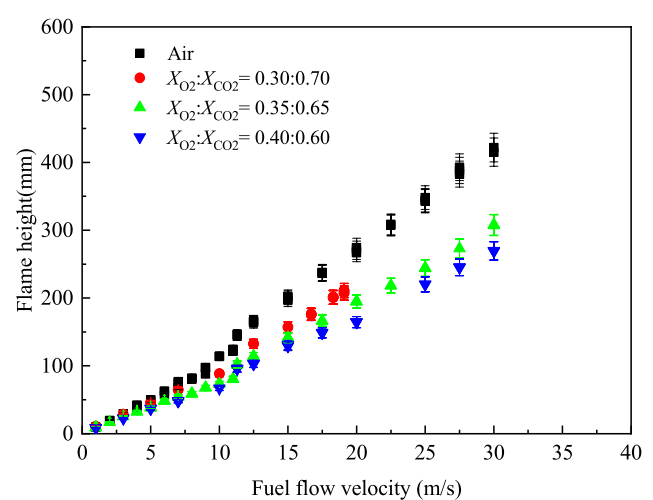

FIGURE 4 | Measured flame heights of $\mathrm{CH}_{4}$-jet-flames in $\mathrm{O}_{2} / \mathrm{CO}_{2}$ and air coflows with $5 \%$ error bars.

The experimental results in Figures 2, 3 show that the luminosity of the flame in the $\mathrm{O}_{2} / \mathrm{CO}_{2}$ coflow is different from that of the laminar $\mathrm{CH}_{4}$ jet flame in air. Both the laminar $\mathrm{CH}_{4}$ jet flames in the air and $\mathrm{O}_{2} / \mathrm{CO}_{2}$ coflows can be divided into two sections, bottom and top partitions, based on the flame luminosity. The bottom section of the flame is dominated by the blue color luminosity, while the top partition of flame shows orange and yellow colors for the flame in $\mathrm{O}_{2} / \mathrm{CO}_{2}$ and air respectively. It can be seen that the bottom section of the flame with $\mathrm{O}_{2} / \mathrm{CO}_{2}$ coflow show dark blue color, however, the flame in air is more bright. The luminosities of the laminar $\mathrm{CH}_{4}$ jet flames in $\mathrm{O}_{2} / \mathrm{CO}_{2}$ and air coflows suggests that the effect of $\mathrm{CO}_{2}$ on the flame structure is remarkable, which needs further investigation.

The flame height of laminar $\mathrm{CH}_{4}$ jet flames in $\mathrm{O}_{2} / \mathrm{CO}_{2}\left(X_{\mathrm{O} 2}=\right.$ $0.30,0.35$ and 0.40 ) and air coflows were measured, as shown in

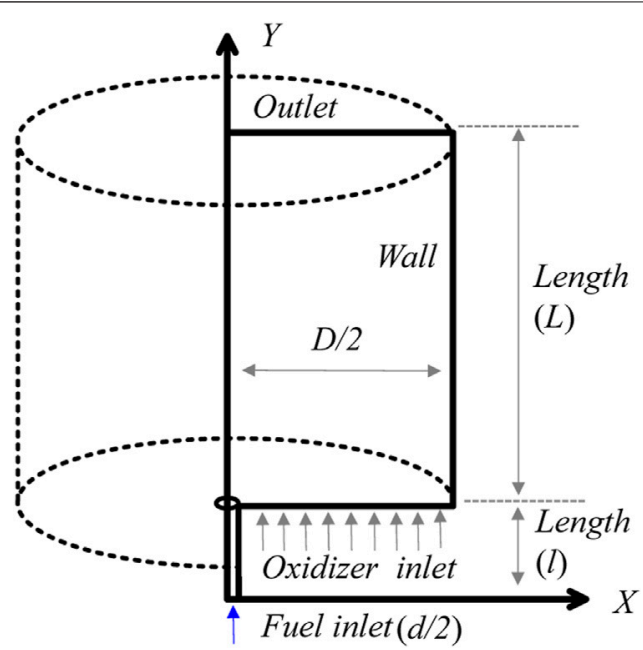

FIGURE 5 | Physical model and boundary conditions.

Figure 4. It can be seen that the flame height is smoothly decreased as the increase of oxygen mole fraction. The flame in air is taller than those of the flames in $\mathrm{O}_{2} / \mathrm{CO}_{2}$ coflows. The theoretical study on the flame length of non-premixed laminar jet flame was conducted in the early studies (Roper, 1977; Roper et al., 1977), and the formula of the flame length for circular port burner was obtained and shown as follows,

$$
L_{\mathrm{f}}=\frac{Q\left(T_{0} / T_{F}\right)}{4 \pi D_{0} \operatorname{In}\left(1+\frac{1}{S}\right)}\left(T_{0} / T_{\mathrm{f}}\right)^{0.67}
$$

Where $T_{0}, T_{\mathrm{F}}$ and $T_{\mathrm{f}}$ are the ambient temperature, the fuel flow temperature and the average temperature of the flame respectively. $Q$ is the volumetric flow rate of fuel stream, $S$ is the stoichiometric molar ratio of oxidizer to fuel. $D_{0}$ is the diffusion coefficient at $T_{0}$. The increase of oxygen concertation leads a decrease of the stoichiometric molar ratio of oxidizer to fuel and an increase of the flame temperature. Consequently the laminar flame height in the $\mathrm{O}_{2} / \mathrm{CO}_{2}$ coflow with a higher oxygen concentration is lower.

\section{NUMERICAL COMPUTATION AND ANALYSIS}

\section{Physical Model and Computation Method}

Numerical computation with a detailed reaction mechanism was conducted to clarify the effects of $\mathrm{CO}_{2}$ on the combustion characteristics of the laminar $\mathrm{CH}_{4}$ jet flame in $\mathrm{O}_{2} / \mathrm{CO}_{2}$ colfow. Figure 5 illustrates the physical model and boundary conditions. A $\mathrm{CH}_{4}$ stream was injected into the $\mathrm{O}_{2} / \mathrm{CO}_{2}$ coflow through a tube with an inner diameter $(d)$ of $1 \mathrm{~mm}$ and a length $(L)$ of $15 \mathrm{~cm}$. The length $(L)$ and width $(D / 2)$ of the computation domain are 50 and $4.6 \mathrm{~cm}$, respectively. $\mathrm{An} \mathrm{O}_{2} / \mathrm{CO}_{2}$ mixture with an $\mathrm{O}_{2}$ mole fraction $\left(X_{\mathrm{O}}\right)$ of 0.35 was used in the study, since the previous work has shown that the counterflow non-premixed $\mathrm{CH}_{4}$ flame in an $\mathrm{O}_{2} / \mathrm{CO}_{2}$ coflow with $X_{\mathrm{O}}=0.35$ has a combustion 
TABLE 1 | Properties of artificial species.

\begin{tabular}{lccc} 
& $\mathbf{K C O}_{\mathbf{2}}$ & $\mathbf{X C O}_{\mathbf{2}}$ & $\mathbf{D C O}_{\mathbf{2}}$ \\
\hline Chemical effect as $\mathrm{CO}_{2}$ & $\times$ & $\times$ & $\sqrt{ }$ \\
Third-body effects as $\mathrm{CO}_{2}$ & $\sqrt{ }$ & $\times$ & $\sqrt{ }$ \\
Thermal properties as $\mathrm{CO}_{2}$ & $\sqrt{ }$ & $\sqrt{ }$ & $\sqrt{ }$ \\
Transport properties as $\mathrm{CO}_{2}$ & $\sqrt{ }$ & $\sqrt{ }$ & $\times$ \\
\hline
\end{tabular}

intensity comparable with that of an air flame (Maruta et al., 2007; Li et al., 2014). The pressure in the system was $1 \mathrm{~atm}$, and the inlet temperature of the oxidizer and fuel streams was $300 \mathrm{~K}$. Laminar non-premixed $\mathrm{CH}_{4}$ jet flames with two different fuel jet velocities ( $V_{\mathrm{F}}=5$ and $10 \mathrm{~m} / \mathrm{s}, \mathrm{Re}=293$ and 586) were investigated. The inlet flow velocity of the oxidizer stream was fixed at $0.1 \mathrm{~m} / \mathrm{s}$. The laminar non-premixed jet flame was simplified to a twodimensional axisymmetric swirl model. All walls were considered to be in a no-slip state. A convective heat transfer boundary (ambient temperature, $300 \mathrm{~K}$; convective heat transfer coefficient, $6 \mathrm{~W} / \mathrm{m}^{2} \cdot \mathrm{K}$ ) based on the experimental conditions was used for the wall of the computational domain, and an adiabatic wall condition was applied to the fuel tube wall. While the velocity inlet boundary was used at the fuel and oxidizer inlets, the pressure outlet boundary was applied at the outlet.

The governing equations included the mass, momentum, energy, and species-conservation equations, as well as the ideal gas equation of state. A detailed description of the governing equations can be found elsewhere (Li et al., 2017). The governing equations were discretized based on the finite-volume method, and the open-source framework, OpenFOAM (OpenFOAM, 2016) was employed to conduct the numerical study. The SIMPLE algorithm was used. The finite rate chemistry model and the GRI-Mech 3.0 mechanism (Smith et al., 2020) were also used to compute the chemical reactions. Previous studies on $\mathrm{CO}_{2^{-}}$ diluted flames (Liu et al., 2003; Maruta et al., 2007; Xie et al., 2013; Li et al., 2014; Li et al., 2015) have shown satisfactory performance of the mechanism. The diffusion coefficient was calculated using the Maxwell-Stefan equations. The thermal diffusion effect was also included in the calculations. Mesh independence was confirmed by preliminary numerical computations. Grids with 136320 cells were used, and the finest grid size was $45 \mu \mathrm{m}$. The values of $1.0 \times 10^{-6}$ and $1.0 \times 10^{-8}$ were used as convergence criteria for the mass and energy conservation equations and chemical reactions, respectively. Radiation heat transfer from the gases was not included in the computation, since the present work primarily focuses on comparisons of the effects of the chemical reactions, third-body collisions, and transport properties of $\mathrm{CO}_{2}$. A discussion on the radiation of $\mathrm{CO}_{2}$ on nonpremixed flames can be found elsewhere (Maruta et al., 2007).

Additional computations using three artificial species modified from $\mathrm{CO}_{2}$ were conducted to analyze the effects of the chemical reactions, third-body reactions, and transport properties of $\mathrm{CO}_{2}$ on the combustion characteristics of the laminar non-premixed jet flame. The properties of the artificial species are listed in Table $\mathbf{1}$. The first artificial species is $\mathrm{KCO}_{2}$, which does not participate in chemical reactions but participates in third-body collisions and has thermal and transport properties identical to those of $\mathrm{CO}_{2}$. The second artificial species is $\mathrm{XCO}_{2}$, which has the same thermal and transport properties as $\mathrm{CO}_{2}$ but does not participate in chemical reactions and third-body collisions. The third artificial species is $\mathrm{DCO}_{2}$, which has the same chemical reactions, third-body effects, and thermal properties as $\mathrm{CO}_{2}$ but transport properties (i.e., thermal conductivities, viscosities, diffusion coefficients,

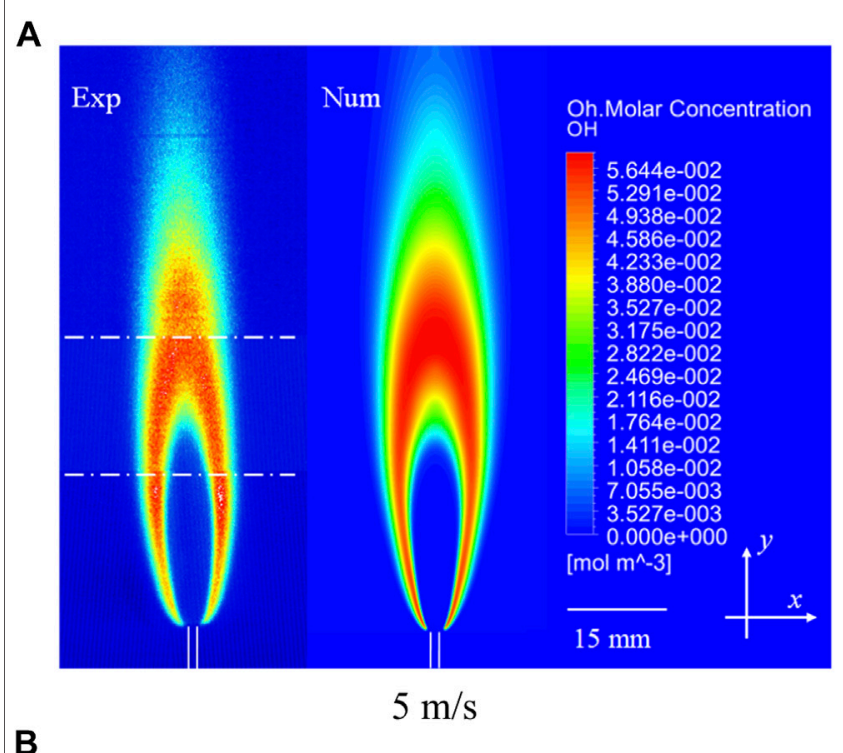

\section{B}

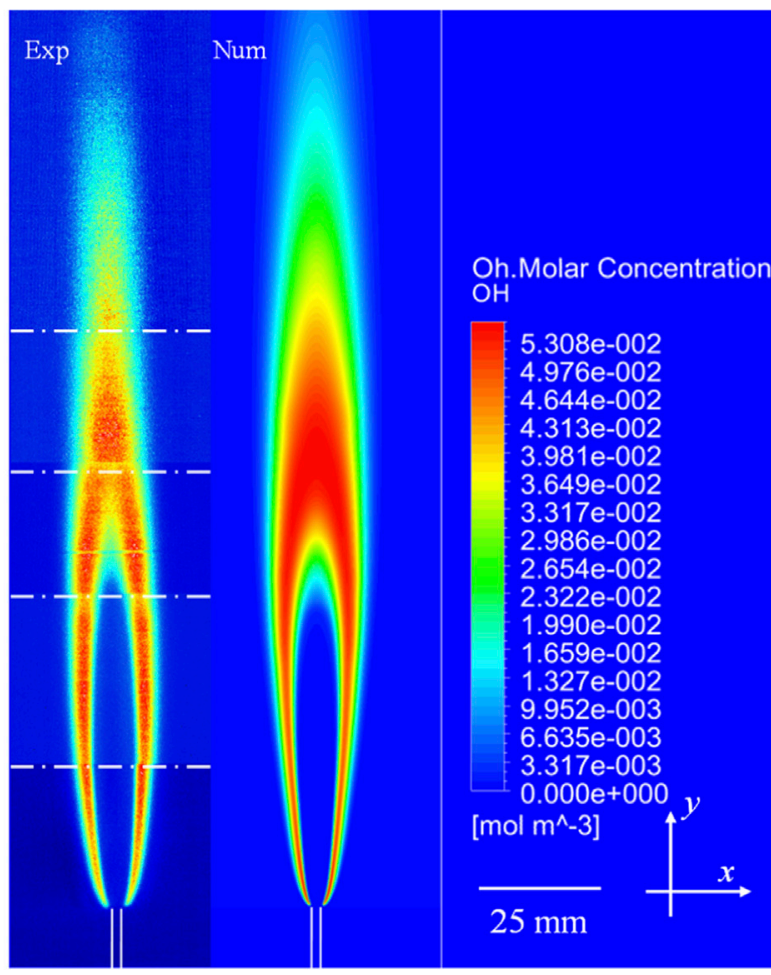

$10 \mathrm{~m} / \mathrm{s}$

FIGURE 6 | Measured and computated $\mathrm{OH}$ distributions of laminar nonpremixed $\mathrm{CH}_{4}$ jet flames in an $\mathrm{O}_{2} / \mathrm{CO}_{2}$ coflow at fuel jet velocities of 5 and $10 \mathrm{~m} / \mathrm{s}$. (A) $5 \mathrm{~m} / \mathrm{s}$. (B) $10 \mathrm{~m} / \mathrm{s}$. 


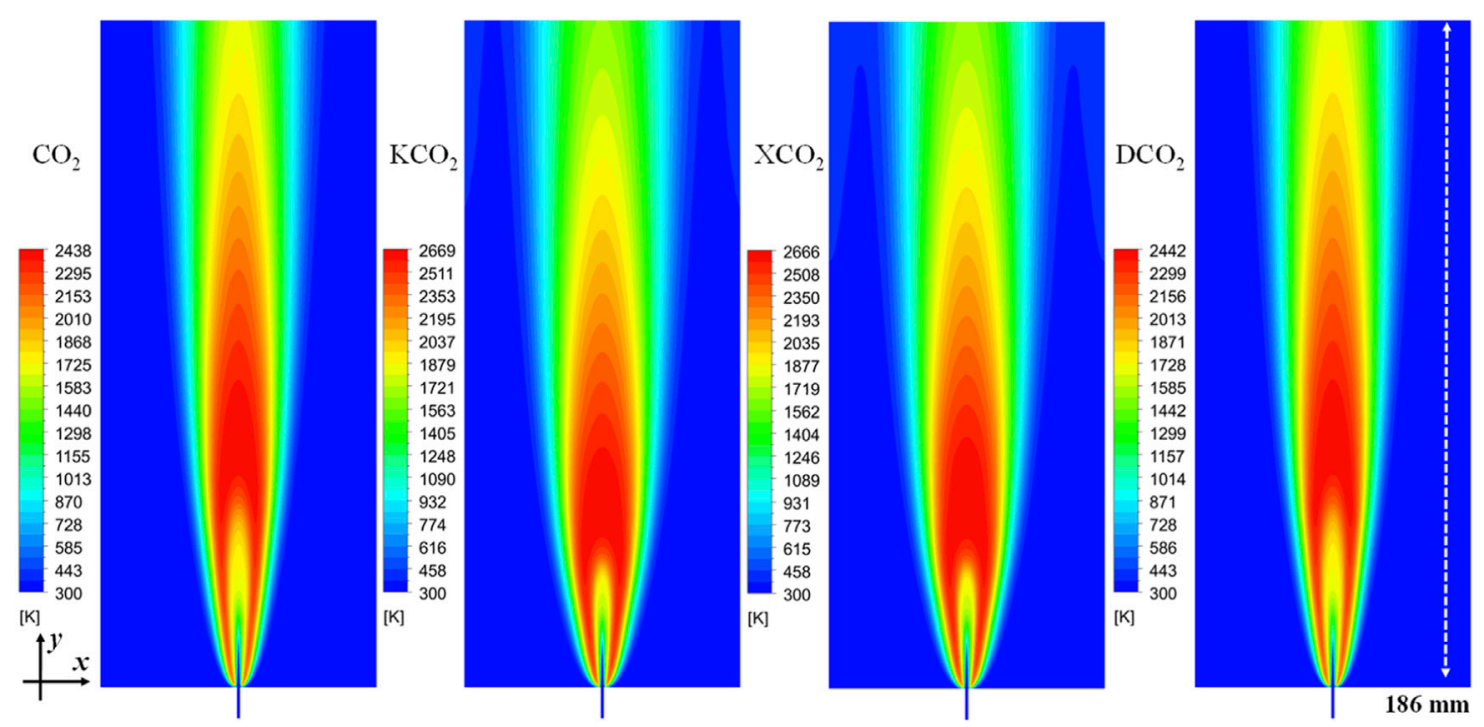

FIGURE 7 | Computational temperature distributions in flames in different oxidizers $\left(V_{F}=10 \mathrm{~m} / \mathrm{s}\right)$.
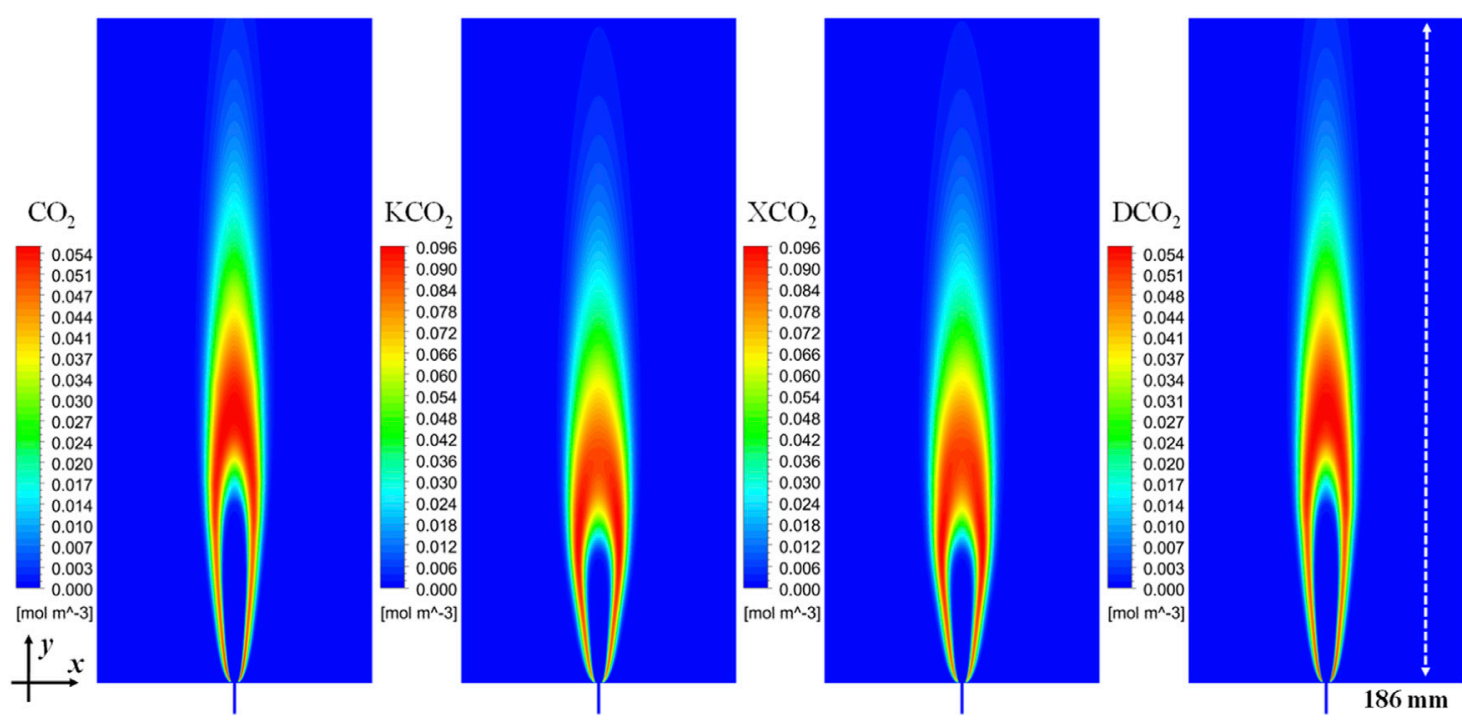

FIGURE 8 | Computational $\mathrm{OH}$ radical distributions in flames in different oxidizers $\left(V_{F}=10 \mathrm{~m} / \mathrm{s}\right)$.

and thermal diffusion coefficients) identical to those of $\mathrm{N}_{2}$. The participation or not of $\mathrm{CO}_{2}$ in the chemical reactions can lead to differences in the computational results between the $\mathrm{CO}_{2}$ and $\mathrm{KCO}_{2}$ conditions. Differences in the combustion characteristics between $\mathrm{KCO}_{2}$ and $\mathrm{XCO}_{2}$ can be attributed to the third-body effects of $\mathrm{CO}_{2}$. The effects of the transport properties of $\mathrm{CO}_{2}$ on the jet flame can be attributed to differences in the computational results between the $\mathrm{DCO}_{2}$ and $\mathrm{CO}_{2}$ cases.

\section{Validation of the Computational Method}

The computational $\mathrm{OH}$ distributions of laminar non-premixed $\mathrm{CH}_{4}$ jet flames at $V_{\mathrm{F}}=5$ and $10 \mathrm{~m} / \mathrm{s}$ were compared with the experimental results, as shown in Figure 6. The total $\mathrm{OH}$ distributions in the flames at fuel jet velocities of 5 and $10 \mathrm{~m} / \mathrm{s}$ consist of three and five parts, respectively. It can be seen that the shape and height determined from the computational $\mathrm{OH}$ distributions are consistent with the results obtained from the experiment. The small difference between the computational and experimental $\mathrm{OH}$ distributions may be attributed to two reasons: the laser sheet is not perfectly set at the center of the flame and is slightly inclined and the computational method assumes a twodimensional physical model and neglects radiation heat loss. Despite minor differences can be observed between the measured and computational $\mathrm{OH}$ distributions, the 


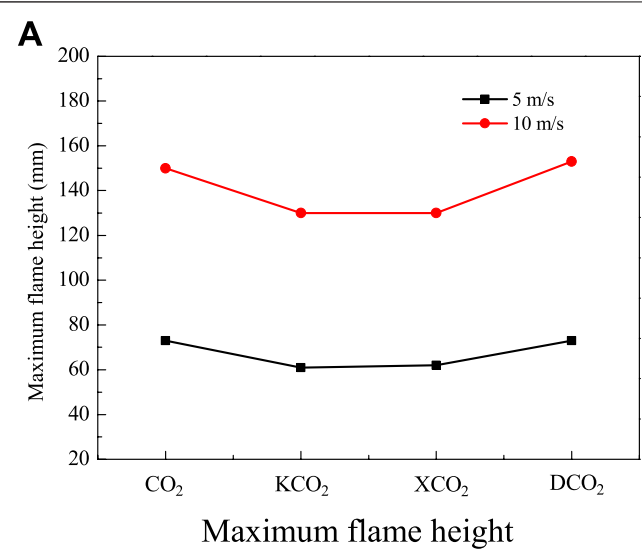

B

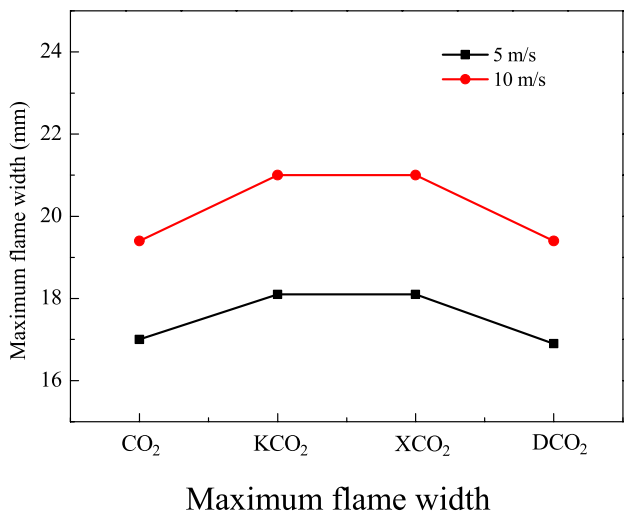

FIGURE 9 | Computational flame height and width based on $\mathrm{OH}$ distributions in laminar non-premixed $\mathrm{CH}_{4}$ jet flames in different oxidizers. (A) Maximum flame height. (B) Maximum flame width.

comparison of the overall results indicates that the present computational method and kinetic mechanism are reasonable for the study of the effects of $\mathrm{CO}_{2}$ on the combustion characteristics of laminar non-premixed $\mathrm{CH}_{4}$ jet flames in an $\mathrm{O}_{2} / \mathrm{CO}_{2}$ coflow with a high $\mathrm{O}_{2}$ concentration.

\section{Effects of $\mathrm{CO}_{2}$ on Flame Temperature and Shape}

The computational results of jet flames in $\mathrm{O}_{2} / \mathrm{CO}_{2}, \mathrm{O}_{2} / \mathrm{KCO}_{2}, \mathrm{O}_{2} /$ $\mathrm{XCO}_{2}$, and $\mathrm{O}_{2} / \mathrm{DCO}_{2}$ coflows were obtained and compared. Figures 7,8 respectively show the temperature and $\mathrm{OH}$ distributions in laminar non-premixed jet flames at $V_{\mathrm{F}}=$ $10 \mathrm{~m} / \mathrm{s}$. The flames in the $\mathrm{O}_{2} / \mathrm{CO}_{2}$ and $\mathrm{O}_{2} / \mathrm{DCO}_{2}$ coflows are nearly identical, and the flames in $\mathrm{O}_{2} / \mathrm{KCO}_{2}$ and $\mathrm{O}_{2} / \mathrm{XCO}_{2}$ coflows are almost the same. Comparison of flames in the $\mathrm{O}_{2} /$ $\mathrm{KCO}_{2}$ and $\mathrm{O}_{2} / \mathrm{XCO}_{2}$ coflows indicates that the contribution of the third-body effects of $\mathrm{CO}_{2}$ on the shape and temperature distribution of the laminar jet flame is insignificant. The results of flames in the $\mathrm{O}_{2} / \mathrm{CO}_{2}$ and $\mathrm{O}_{2} / \mathrm{DCO}_{2}$ coflows reveal that the difference in transport properties between $\mathrm{CO}_{2}$ and $\mathrm{N}_{2}$ also does not lead to a significant change in the flames. However, the difference between the flames in the $\mathrm{O}_{2} / \mathrm{CO}_{2}$ and $\mathrm{O}_{2} / \mathrm{KCO}_{2}$ coflows suggests that the flame shape and temperature

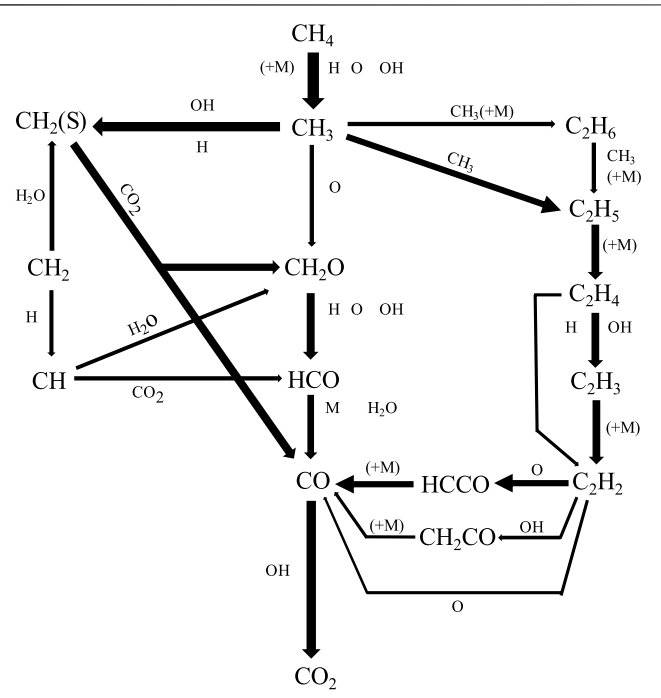

FIGURE 10 | Integral reaction flow in a laminar non-premixed $\mathrm{CH}_{4}$ jet flame in an $\mathrm{O}_{2} / \mathrm{CO}_{2}$ coflow at $V_{\mathrm{F}}=10 \mathrm{~m} / \mathrm{s}$ (thick lines show the major reactions).

distribution of laminar non-premixed jet flames are significantly changed by the chemical effects of $\mathrm{CO}_{2}$. Specifically, the flame height is decreased, whereas the maximum flame width is increased, when the chemical effects of $\mathrm{CO}_{2}$ are excluded from consideration. The decrease in the maximum flame temperature by the chemical effect of $\mathrm{CO}_{2}$ is approximately $230 \mathrm{~K}$.

The detailed computational results of laminar non-premixed $\mathrm{CH}_{4}$ jet flames in $\mathrm{O}_{2} / \mathrm{CO}_{2}, \mathrm{O}_{2} / \mathrm{KCO}_{2}, \mathrm{O}_{2} / \mathrm{XCO}_{2}$, and $\mathrm{O}_{2} / \mathrm{DCO}_{2}$ coflows at a fuel flow velocities of 5 and $10 \mathrm{~m} / \mathrm{s}$ were analyzed. The flame heights and widths based on the $\mathrm{OH}$ distribution in flames in different oxidizers at $V_{\mathrm{F}}=5$ and $10 \mathrm{~m} / \mathrm{s}$ are illustrated in Figures 9A,B, respectively. The flame boundaries are judged by 99\% decrease of the maximum $\mathrm{OH}$ molar concentration. The variations in the flame height and width of laminar non-premixed $\mathrm{CH}_{4}$ jet flames at $V_{\mathrm{F}}=5 \mathrm{~m} / \mathrm{s}$ in different oxidizer coflows are similar to those of flames at $V_{\mathrm{F}}=10 \mathrm{~m} / \mathrm{s}$. Although not shown here, the numerical results indicate that the maximum flame temperatures at $V_{\mathrm{F}}=5 \mathrm{~m} / \mathrm{s}$ in $\mathrm{O}_{2} / \mathrm{CO}_{2}$ and $\mathrm{O}_{2} / \mathrm{DCO}_{2}$ are nearly identical, i.e., $2470 \mathrm{~K}$, and the maximum flame temperatures in $\mathrm{O}_{2} / \mathrm{KCO}_{2}$ and $\mathrm{O}_{2} / \mathrm{XCO}_{2}$ are similar, i.e., approximately $2670 \mathrm{~K}$. The computational $\mathrm{OH}$ distributions show that flame height decreases, whereas flame width increases, when the chemical effect of $\mathrm{CO}_{2}$ is suspended.

\section{Mechanism of $\mathrm{CO}_{2}$ on the Laminar Non-Premixed $\mathrm{CH}_{4}$ Jet Flames}

The reaction pathways and flame structures in $\mathrm{O}_{2} / \mathrm{CO}_{2}, \mathrm{O}_{2} /$ $\mathrm{KCO}_{2}, \mathrm{O}_{2} / \mathrm{XCO}_{2}$ and $\mathrm{O}_{2} / \mathrm{DCO}_{2}$ were analyzed to interpret the mechanism of the chemical effect of $\mathrm{CO}_{2}$ on laminar nonpremixed $\mathrm{CH}_{4}$ jet flames. The primary reaction pathways of flames in the $\mathrm{O}_{2} / \mathrm{KCO}_{2}, \mathrm{O}_{2} / \mathrm{XCO}_{2}$, and $\mathrm{O}_{2} / \mathrm{DCO}_{2}$ coflows are nearly identical to those of flames in the $\mathrm{O}_{2} / \mathrm{CO}_{2}$ coflow. 


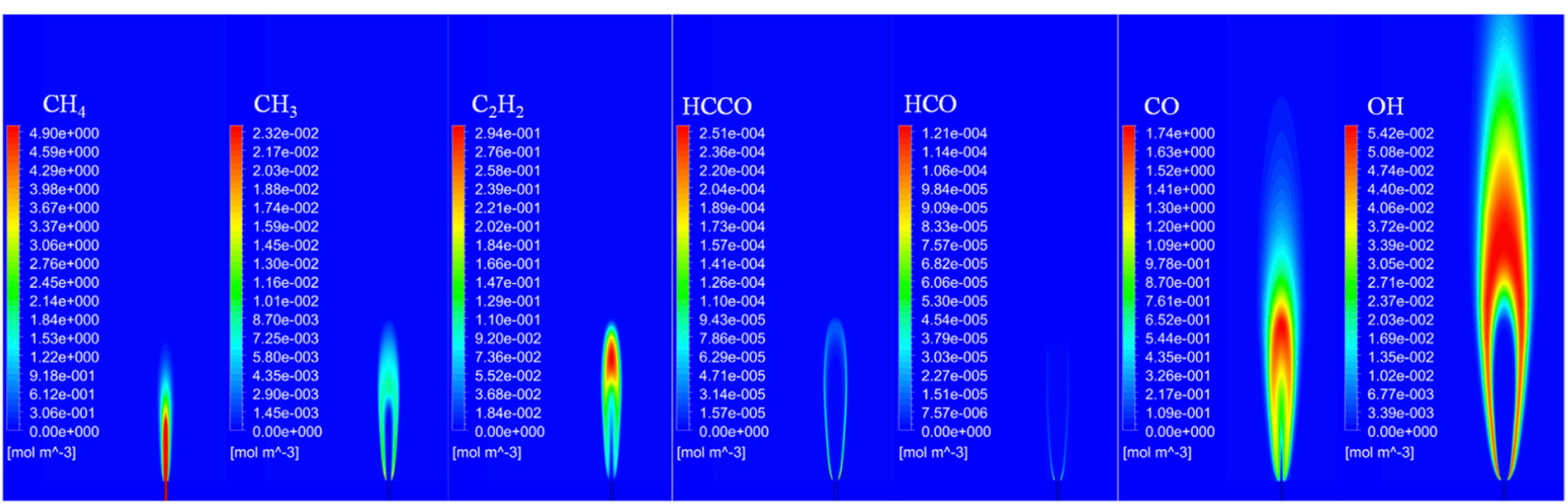

FIGURE 11 | Molar concentrations of important species in a laminar non-premixed $\mathrm{CH}_{4}$ jet flame in an $\mathrm{O}_{2} / \mathrm{CO}_{2}$ coflow $\left(V_{\mathrm{F}}=10 \mathrm{~m} / \mathrm{s}\right)$.

Figure 10 shows the global reaction pathways of laminar nonpremixed flames in the $\mathrm{O}_{2} / \mathrm{CO}_{2}$ coflow at $V_{\mathrm{F}}=10 \mathrm{~m} / \mathrm{s}$. $\mathrm{CH}_{4}$ is transformed into $\mathrm{CH}_{3}$ through $\mathrm{H}$ abstraction by $\mathrm{H}, \mathrm{O}$, and $\mathrm{OH}$. Most of the $\mathrm{CH}_{3}$ radicals are transformed into $\mathrm{C}_{2} \mathrm{H}_{5}, \mathrm{CH}_{2}(\mathrm{~S})$, and $\mathrm{C}_{2} \mathrm{H}_{6}$, and only a small amount of the $\mathrm{CH}_{3}$ radicals react with $\mathrm{O}$ atoms to produce $\mathrm{CH}_{2} \mathrm{O}$. Most of the $\mathrm{C}_{2} \mathrm{H}_{6}$ generated is transformed into $\mathrm{C}_{2} \mathrm{H}_{5}$ through third-body reactions. $\mathrm{C}_{2} \mathrm{H}_{5}$ radicals decompose rapidly into $\mathrm{C}_{2} \mathrm{H}_{4}$, and $\mathrm{H}$ abstraction by $\mathrm{H}$ and $\mathrm{OH}$, which are important sources of $\mathrm{C}_{2} \mathrm{H}_{4}$ consumption, produces $\mathrm{C}_{2} \mathrm{H}_{3}$ radicals. The reaction $\mathrm{C}_{2} \mathrm{H}_{3}(+\mathrm{M})=\mathrm{C}_{2} \mathrm{H}_{2}+\mathrm{H}$ $(+\mathrm{M})$ consumes $\mathrm{C}_{2} \mathrm{H}_{3}$ radicals to produce $\mathrm{C}_{2} \mathrm{H}_{2}$. Most of the $\mathrm{C}_{2} \mathrm{H}_{2}$ is consumed by reaction with $\mathrm{O}$ to produce HCCO. The HCCO radicals generate $\mathrm{CH}$ and $\mathrm{CO}$ via the third-body reaction $\mathrm{HCCO}(+\mathrm{M})=\mathrm{CH}+\mathrm{CO}(+\mathrm{M})$. Finally, $\mathrm{CO}$ is oxidized to $\mathrm{CO}_{2}$ by the reaction $\mathrm{OH}+\mathrm{CO}=\mathrm{H}+\mathrm{CO}_{2}$.

Figure 11 shows the distribution of important species in a laminar non-premixed jet flame in an $\mathrm{O}_{2} / \mathrm{CO}_{2}$ environment at $V_{\mathrm{F}}=10 \mathrm{~m} / \mathrm{s}$. The $\mathrm{CH}_{4}$-rich region can be observed near the exit of the tube, and the $\mathrm{CH}_{3}$-rich region can be observed around the region with a high $\mathrm{CH}_{4}$ concentration. The $\mathrm{C}_{2} \mathrm{H}_{2}$-rich concentration region is located at nearly the same area as the $\mathrm{CH}_{3}$-rich region. The $\mathrm{HCCO}$ is found on the margins of the $\mathrm{C}_{2} \mathrm{H}_{2}$-rich region, and theHCO only exists at the two sides of the $\mathrm{CH}_{3}$-rich region. The molar concentration of the $\mathrm{HCCO}$ is higher than that of the HCO. The CO-rich region is located downstream of the HCCO-rich region.

The analysis of the computational results of flames in the $\mathrm{O}_{2} /$ $\mathrm{KCO}_{2}, \mathrm{O}_{2} / \mathrm{XCO}_{2}$, and $\mathrm{O}_{2} / \mathrm{DCO}_{2}$ coflows shows that the distributions of important species are similar to those of flames in $\mathrm{O}_{2} / \mathrm{CO}_{2}$. Moreover, laminar non-premixed $\mathrm{CH}_{4}$ jet flames in different oxidizers can be divided into two parts based on the global oxidation process. The results of flames in the $\mathrm{O}_{2} /$ $\mathrm{CO}_{2}$ coflow at $V_{\mathrm{F}}=10 \mathrm{~m} / \mathrm{s}$ are illustrated in Figure 12; here, the white dotted line indicates the boundary between the first and second parts of the flame. The first part of the flame includes the oxidation process from $\mathrm{CH}_{4}$ to $\mathrm{CO}$ through the reaction pathway $\mathrm{CH}_{4} \rightarrow \mathrm{CH}_{3} \rightarrow \mathrm{C}_{2} \mathrm{H}_{6} \rightarrow \mathrm{C}_{2} \mathrm{H}_{5} \rightarrow \mathrm{C}_{2} \mathrm{H}_{4} \rightarrow \mathrm{C}_{2} \mathrm{H}_{3} \rightarrow \mathrm{C}_{2} \mathrm{H}_{2} \rightarrow$ $\mathrm{HCCO} \rightarrow \mathrm{CO}$, while the primary reaction in the second part is the oxidation of $\mathrm{CO}$ to $\mathrm{CO}_{2}$. Consequently, the top of the HCCO

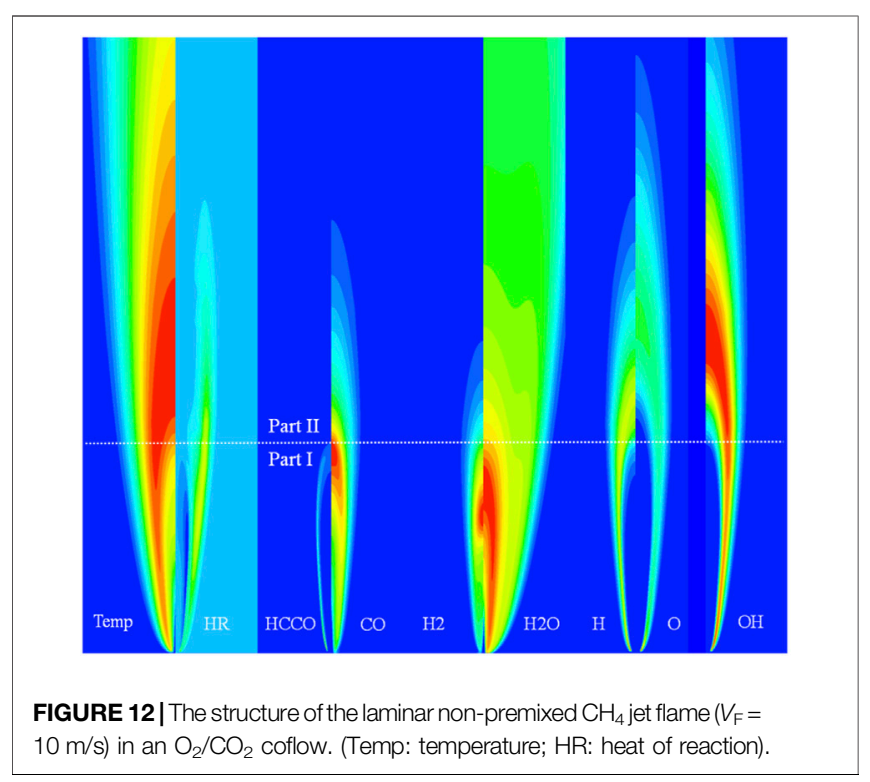

region is used as the boundary separating the first and second parts of the flame. Generation of $\mathrm{H}_{2}$ and $\mathrm{H}_{2} \mathrm{O}$ is mainly completed in the first part of the flame. The distribution of the heats of reaction indicates that the first and second parts of the flame make remarkable contributions to heat generation. A distinct endothermic region is located in the first part of the flame. The effects of $\mathrm{CO}_{2}$ on the first and second typical parts of nonpremixed laminar jet flames result in different combustion characteristics.

The distributions of important species of flames in the $\mathrm{O}_{2} / \mathrm{CO}_{2}$ and $\mathrm{O}_{2} / \mathrm{KCO}_{2}$ coflows were compared to enable interpretation of the chemical effect of $\mathrm{CO}_{2}$ on the laminar non-premixed $\mathrm{CH}_{4}$ jet flame, since the effect of third-body collisions with $\mathrm{CO}_{2}$ on the laminar non-premixed jet flame has been confirmed to be negligible. The distributions of the molar concentrations of $\mathrm{HCCO}, \mathrm{CO}, \mathrm{O}$, and $\mathrm{H}$ in the flames in $\mathrm{O}_{2} / \mathrm{CO}_{2}$ and $\mathrm{O}_{2} / \mathrm{KCO}_{2}$ coflows are shown in Figures 13A-D. The heights of the HCCO-, $\mathrm{CO}-, \mathrm{O}-$, and $\mathrm{H}$-rich regions in the flame in the $\mathrm{O}_{2} / \mathrm{KCO}_{2}$ coflow 

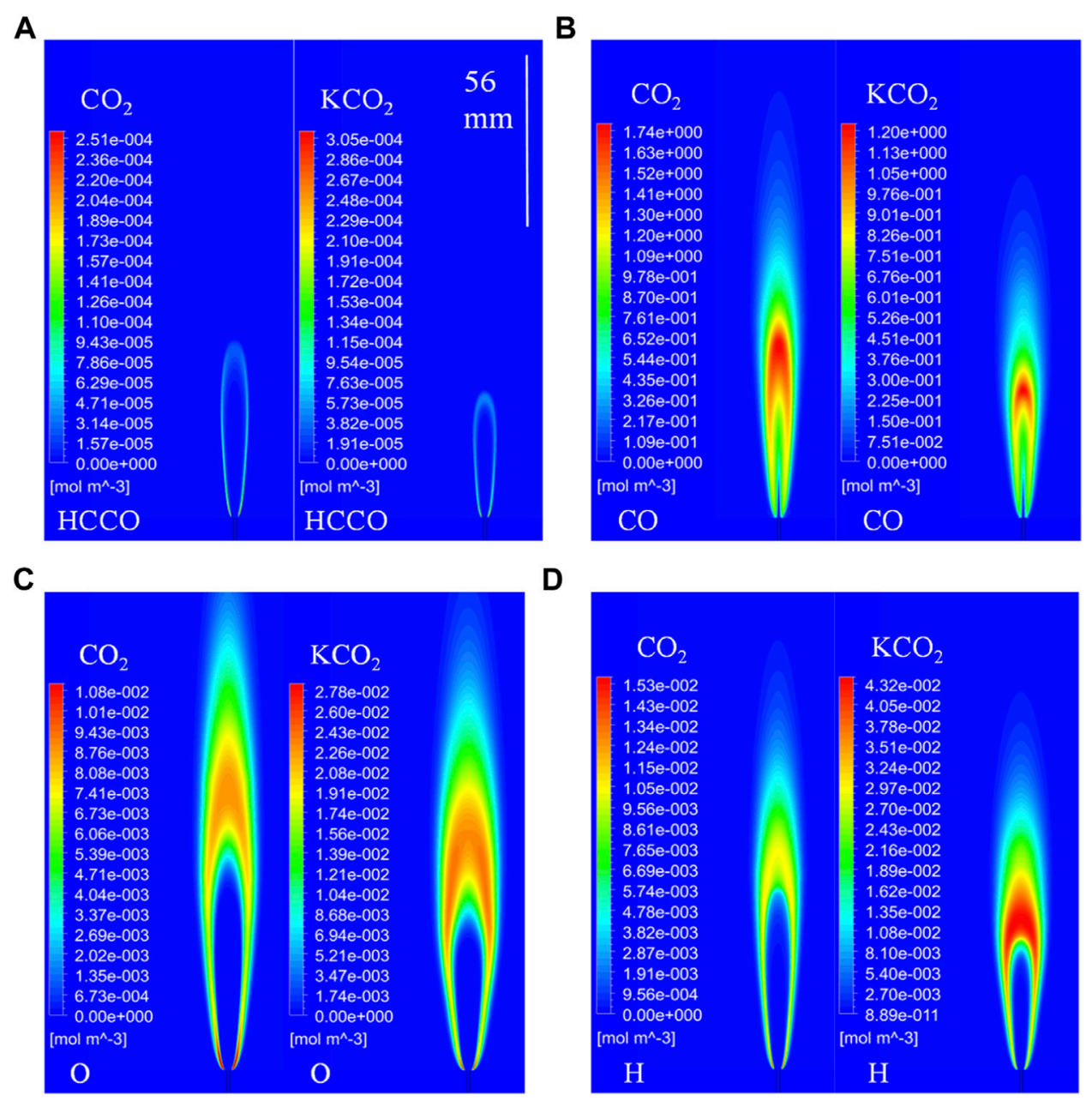

FIGURE 13 | Distributions of the molar concentration of important species in flames in $\mathrm{O}_{2} / \mathrm{CO}_{2}$ and $\mathrm{O}_{2} / \mathrm{KCO}_{2}$ : (A) $\mathrm{HCCO}$, (B) $\mathrm{CO}$, (C) $\mathrm{O}$, and (D) $\mathrm{H}$.

are shorter than those in the flame in the $\mathrm{O}_{2} / \mathrm{CO}_{2}$ coflow. Interestingly, the difference between the heights of the HCCOrich region in the flames in the $\mathrm{O}_{2} / \mathrm{CO}_{2}$ and $\mathrm{O}_{2} / \mathrm{KCO}_{2}$ coflows is nearly identical to that between the heights of the $\mathrm{OH}$-rich regions (as shown in Figure 8). The difference between the flame heights based on the $\mathrm{OH}$ distribution is related to differences in HCCO distribution in the first part of the flame. The analysis of the reaction pathways shows that $\mathrm{HCCO}$ is primarily produced by the reaction $\mathrm{O}+\mathrm{C}_{2} \mathrm{H}_{2}=\mathrm{H}+\mathrm{HCCO}$. As $\mathrm{O}$ atoms are mainly generated by the reaction $\mathrm{H}+\mathrm{O}_{2}=\mathrm{O}+\mathrm{OH}$, the flame height essentially depends on the $\mathrm{H}$ distribution. The contours of the $\mathrm{H}$ molar concentration shown in Figure 13D indicate that the concentration of $\mathrm{H}$ atoms of the flame in $\mathrm{O}_{2} / \mathrm{KCO}_{2}$ is significantly higher than that of the flame in $\mathrm{O}_{2} / \mathrm{CO}_{2}$. Pathway analysis of the entire flame region shows that the reaction $\mathrm{OH}+$ $\mathrm{CO}=\mathrm{H}+\mathrm{CO}_{2}$ is an important source of $\mathrm{H}$ atoms. This finding suggests that the chemical effect of $\mathrm{CO}_{2}$ on $\mathrm{H}$ formation and distribution ultimately leads to a difference in flame heights.

The results shown in Figure $\mathbf{1 2}$ indicate that the hightemperature region and the $\mathrm{OH}$-rich region are coincident, this finding can also be observed from the results shown in
Figures 7, 8. This phenomena is attributed to the fact that the high-temperature region is located in the second part of the laminar non-premixed flame, where the reaction $\mathrm{OH}+\mathrm{CO}=\mathrm{H}+$ $\mathrm{CO}_{2}$ is the primary exothermic reaction. The results shown in Figure 7 indicate that the maximum temperature of the laminar non-premixed flame in the $\mathrm{O}_{2} / \mathrm{CO}_{2}$ coflow is approximately $230 \mathrm{~K}$ lower than that of the flame in the $\mathrm{O}_{2} / \mathrm{KCO}_{2}$ coflow. Although not shown here, analysis of the computational results shows that the net reaction rates of $\mathrm{OH}+\mathrm{CO}=\mathrm{H}+$ $\mathrm{CO}_{2}$ and $\mathrm{H}+\mathrm{O}_{2}=\mathrm{O}+\mathrm{OH}$ of the flame in the $\mathrm{O}_{2} / \mathrm{CO}_{2}$ coflow are lower than those of the flame in the $\mathrm{O}_{2} / \mathrm{KCO}_{2}$ coflow. The net reaction rate of $\mathrm{OH}+\mathrm{CO}=\mathrm{H}+\mathrm{CO}_{2}$ in the second part of the flame is significantly reduced by the chemical effect of $\mathrm{CO}_{2}$, which results in a low flame temperature.

\section{CONCLUSION}

The heights of the laminar $\mathrm{CH}_{4}$ jet flames in $\mathrm{O}_{2} / \mathrm{CO}_{2}$ coflows with different oxygen mole fractions of $0.30,0.35$ and 0.40 were obtained by experimental study. The height of the flame in 
$\mathrm{O}_{2} / \mathrm{CO}_{2}$ coflow decreases as the increase of oxygen mole fraction. And the height of the laminar $\mathrm{CH}_{4}$ jet flame in $\mathrm{O}_{2} / \mathrm{CO}_{2}$ coflow with oxygen mole fraction of 0.30 is shorter than that of the laminar $\mathrm{CH}_{4}$ jet flame in air. Moreover, the luminosity of the $\mathrm{CH}_{4}$ jet flame in $\mathrm{O}_{2} / \mathrm{CO}_{2}$ coflow is totally different from that of the flame in air stream.

The chemical reactions, third-body effects, and transport properties of $\mathrm{CO}_{2}$ on the combustion characteristics of a laminar non-premixed $\mathrm{CH}_{4}$ jet flame in an $\mathrm{O}_{2} / \mathrm{CO}_{2}$ coflow with a high $\mathrm{O}_{2}$ concentration $\left(X_{\mathrm{O}}=0.35\right)$ were investigated using a two-dimensional numerical computational method with a detailed kinetic mechanism. The computational $\mathrm{OH}$ distributions showed good consistency with the results obtained from the experiments. Whereas the third-body effect and transport properties of $\mathrm{CO}_{2}$ do not exert remarkable effects on the laminar non-premixed flame, the chemical effect of $\mathrm{CO}_{2}$ on the laminar non-premixed jet flame is significant. The chemical effect of $\mathrm{CO}_{2}$ increases the flame height but decreases the maximum flame temperature. The primary oxidation pathway in the jet flame is $\mathrm{CH}_{4} \rightarrow \mathrm{CH}_{3} \rightarrow \mathrm{C}_{2} \mathrm{H}_{6} \rightarrow$ $\mathrm{C}_{2} \mathrm{H}_{5} \rightarrow \mathrm{C}_{2} \mathrm{H}_{4} \rightarrow \mathrm{C}_{2} \mathrm{H}_{3} \rightarrow \mathrm{C}_{2} \mathrm{H}_{2} \rightarrow \mathrm{HCCO} \rightarrow \mathrm{CO} \rightarrow \mathrm{CO}_{2}$. The $\mathrm{CH}_{4}$ non-premixed laminar jet flame can be divided into two parts based on the global oxidization process; here, the top of the HCCO-rich region is the boundary between these parts. The decrease in the concentration of $\mathrm{O}$ atoms by the chemical effect of $\mathrm{CO}_{2}$ in the first part of the flame can explain the observed

\section{REFERENCES}

Buhre, B. J. P., Elliott, L. K., Sheng, C. D., Gupta, R. P., and Wall, T. F. (2005). Oxyfuel Combustion Technology for Coal-Fired Power Generation. Prog. Energ. Combustion Sci. 31, 283-307. doi:10.1016/j.pecs.2005.07.001

Bürkle, S., Dreizler, A., Ebert, V., and Wagner, S. (2018). Experimental Comparison of a 2D Laminar Diffusion Flame under Oxy-Fuel and Air Atmosphere. Fuel 212, 302-308. doi:10.1016/j.fuel.2017.10.067

Chen, L., Yong, S. Z., and Ghoniem, A. F. (2012). Oxy-fuel Combustion of Pulverized Coal: Characterization, Fundamentals, Stabilization and CFD Modeling. Prog. Energ. Combustion Sci. 38, 156-214. doi:10.1016/j.pecs. 2011.09.003

Dhaneswar, S. R., and Pisupati, S. V. (2012). Oxy-fuel Combustion: The Effect of Coal Rank and the Role of char-CO2 Reaction. Fuel Process. Technol. 102, 156-165. doi:10.1016/j.fuproc.2012.04.029

Ge, X., Dong, J., Fan, H., Zhang, Z., Shang, X., Hu, X., et al. (2017). Numerical Investigation of Oxy-Fuel Combustion in $700^{\circ} \mathrm{C}$-Ultra-Supercritical Boiler. Fuel 207, 602-614. doi:10.1016/j.fuel.2017.06.119

Giménez-López, J., Millera, A., Bilbao, R., and Alzueta, M. U. (2015). Experimental and Kinetic Modeling Study of the Oxy-Fuel Oxidation of Natural Gas, $\mathrm{CH}_{4}$ and $\mathrm{C}_{2} \mathrm{H}_{6}$. Fuel 160, 404-412. doi:10.1016/j.fuel.2015.07.087

Gładysz, P., Stanek, W., Czarnowska, L., Sładek, S., and Szlęk, A. (2018). Thermoecological Evaluation of an Integrated MILD Oxy-Fuel Combustion Power Plant with $\mathrm{CO}_{2}$ Capture, Utilisation, and Storage - A Case Study in Poland. Energy 144, 379-392. doi:10.1016/j.energy.2017.11.133

Glarborg, P., and Bentzen, L. L. B. (2008). Chemical Effects of a High $\mathrm{CO}_{2}$ Concentration in Oxy-Fuel Combustion of Methane. Energy Fuels 22, 291-296. doi:10.1021/ef7005854

Hjärtstam, S., Andersson, K., Johnsson, F., and Leckner, B. (2009). Combustion Characteristics of lignite-fired Oxy-Fuel Flames. Fuel 88, 2216-2224. doi:10. 1016/j.fuel.2009.05.011

Kobayashi, H., Hagiwara, H., Kaneko, H., and Ogami, Y. (2007). Effects of $\mathrm{CO}_{2}$ Dilution on Turbulent Premixed Flames at High Pressure and High decrease in flame height, and the inhibitory effect of $\mathrm{CO}_{2}$ on the reaction rate of $\mathrm{OH}+\mathrm{CO}=\mathrm{H}+\mathrm{CO}_{2}$ in the second part of the flame induces a decrease in maximum flame temperature.

\section{DATA AVAILABILITY STATEMENT}

The original contributions presented in the study are included in the article/supplementary material, further inquiries can be directed to the corresponding author.

\section{AUTHOR CONTRIBUTIONS}

FZ: Laser diagnostic, Data analysis, Reviewing and editing. XL: Conceptualization, Supervision, Methodology, Investigation, Reviewing and editing, Funding acquisition. SX: Data Curation, Reviewing and editing. JW: Data Curation, Reviewing and editing. XW: Reviewing and editing.

\section{FUNDING}

The supports of National Natural Science Foundation of China (No. 52176139) and the DNL Cooperation Fund, CAS (DNL202006) are gratefully acknowledged.

Temperature. Proc. Combust. Inst. 31, 1451-1458. doi:10.1016/j.proci.2006. 07.159

Kobayashi, H., Yata, S., Ichikawa, Y., and Ogami, Y. (2009). Dilution Effects of Superheated Water Vapor on Turbulent Premixed Flames at High Pressure and High Temperature. Proc. Combust. Inst. 32, 2607-2614. doi:10.1016/j.proci. 2008.05.078

Li, P., Dally, B. B., Mi, J., and Wang, F. (2013). MILD Oxy-Combustion of Gaseous Fuels in a Laboratory-Scale Furnace. Combust. Flame 160, 933-946. doi:10. 1016/j.combustflame.2013.01.024

Li, X., Jia, L., Nakamura, H., Tezuka, T., Hasegawa, S., and Maruta, K. (2015). Study on Flame Responses and Ignition Characteristics of $\mathrm{CH}_{4} / \mathrm{O}_{2} / \mathrm{CO}_{2}$ Mixture in a Micro Flow Reactor with a Controlled Temperature Profile. Appl. Therm. Eng. 84, 360-367. doi:10.1016/j.applthermaleng.2015.03.022

Li, X., Jia, L., Onishi, T., Grajetzki, P., Nakamura, H., Tezuka, T., et al. (2014). Study on Stretch Extinction Limits of $\mathrm{CH}_{4} / \mathrm{CO}_{2}$ versus High Temperature $\mathrm{O}_{2} / \mathrm{CO}_{2}$ Counterflow Non-premixed Flames. Combust. Flame 161, 1526-1536. doi:10. 1016/j.combustflame.2013.12.004

Li, X., Yang, H., Jiang, L., Wang, X., and Zhao, D. (2016). Stretch Extinction Characteristics of $\mathrm{CH}_{4} / \mathrm{CO}_{2}$ versus $\mathrm{O}_{2} / \mathrm{H}_{2} \mathrm{O} / \mathrm{CO}_{2}$ and $\mathrm{O}_{2} / \mathrm{H}_{2} \mathrm{O}$ Counterflow Non-premixed Flames at Different Oxidizer Temperatures. Fuel 186, 648-655. doi:10.1016/j.fuel.2016.09.017

Li, X., Zhang, J., Yang, H., Jiang, L., Wang, X., and Zhao, D. (2017). Combustion Characteristics of Non-premixed Methane Micro-jet Flame in Coflow Air and thermal Interaction between Flame and Micro Tube. Appl. Therm. Eng. 112, 296-303. doi:10.1016/j.applthermaleng.2016.10.082

Liu, D., Wall, T., and Stanger, R. (2016). $\mathrm{CO}_{2}$ Quality Control in Oxy-Fuel Technology for CCS: $\mathrm{SO}_{2}$ Removal by the Caustic Scrubber in Callide Oxy-Fuel Project. Int. J. Greenhouse Gas Control. 51, 207-217. doi:10.1016/j.ijggc.2016.05.026

Liu, F., Guo, H., and Smallwood, G. J. (2003). The Chemical Effect of $\mathrm{CO}_{2}$ Replacement of $\mathrm{N}_{2}$ in Air on the Burning Velocity of $\mathrm{CH}_{4}$ and $\mathrm{H}_{2}$ Premixed Flames. Combust. Flame 133, 495-497. doi:10.1016/s0010-2180(03)00019-1

Luo, W., Wang, Q., Huang, X., Liu, Z., and Zheng, C. (2015). Dynamic Simulation and Transient Analysis of a 3MWth Oxy-Fuel Combustion System. Int. J. Greenhouse Gas Control. 35, 138-149. doi:10.1016/j.ijggc.2015.02.003 
Mao, Z., Zhang, L., Zhu, X., and Zheng, C. (2017). Experiment Investigation of Coal MILD-Oxy Combustion Integrated with Flue Gas Recirculation at a 0.3MWth Furnace. Fuel Process. Technol. 162, 126-134. doi:10.1016/j.fuproc.2017.04.002

Mardani, A., and Fazlollahi Ghomshi, A. (2016). Numerical Study of Oxy-Fuel MILD (Moderate or Intense Low-Oxygen Dilution Combustion) Combustion for $\mathrm{CH}_{4}-\mathrm{H}_{2}$ Fuel. Energy 99, 136-151. doi:10.1016/j.energy.2016.01.016

Maruta, K., Abe, K., Hasegawa, S., Maruyama, S., and Sato, J. (2007). Extinction Characteristics of $\mathrm{CH}_{4} / \mathrm{CO}_{2}$ versus $\mathrm{O}_{2} / \mathrm{CO}_{2}$ Counterflow Non-premixed Flames at Elevated Pressures up to 0.7MPa. Proc. Combust. Inst. 31, 1223-1230. doi:10. 1016/j.proci.2006.08.013

Menage, D., Lemaire, R., and Seers, P. (2018). Experimental Study and Chemical Reactor Network Modeling of the High Heating Rate Devolatilization and Oxidation of Pulverized Bituminous Coals under Air, Oxygen-Enriched Combustion (OEC) and Oxy-Fuel Combustion (OFC). Fuel Process. Technol. 177, 179-193. doi:10.1016/j.fuproc.2018.04.025

Moroń, W., and Rybak, W. (2015). Ignition Behaviour and Flame Stability of Different Ranks Coals in Oxy Fuel Atmosphere. Fuel 161, 174-181. doi:10. 1016/j.fuel.2015.08.065

Oh, J., and Hong, S. (2016). Oxygen Temperature Variation of a Non-premixed Oxy-Methane Flame in a Lab-Scale Slot Burner. Appl. Therm. Eng. 104, 804-817. doi:10.1016/j.applthermaleng.2016.05.112

Oh, J., and Noh, D. (2015). Flame Characteristics of a Non-premixed Oxy-Fuel Jet in a Lab-Scale Furnace. Energy 81, 328-343. doi:10.1016/j.energy.2014.12.046

Oh, J., Noh, D., and Ko, C. (2013). The Effect of Hydrogen Addition on the Flame Behavior of a Non-premixed Oxy-Methane Jet in a Lab-Scale Furnace. Energy 62, 362-369. doi:10.1016/j.energy.2013.09.049

Oh, J., Noh, D., and Lee, E. (2013). The Effect of CO Addition on the Flame Behavior of a Non-premixed Oxy-Methane Jet in a Lab-Scale Furnace. Appl. Energ. 112, 350-357. doi:10.1016/j.apenergy.2013.06.033

Oh, J., and Noh, D. (2013). Lifted Flame Behavior of a Non-premixed OxyMethane Jet in a Lab-Scale Slot Burner. Fuel 103, 862-868. doi:10.1016/j.fuel. 2012.09.055

Oh, J., and Noh, D. (2014). The Effect of $\mathrm{CO}_{2}$ Addition on the Flame Behavior of a Non-premixed Oxy-Methane Jet in a Lab-Scale Furnace. Fuel 117, 79-86. doi:10.1016/j.fuel.2013.08.065

OpenFOAM The Open Source CFD Toolbox. 2016 Available at: http://www. openfoam.org.

Rathnam, R. K., Elliott, L. K., Wall, T. F., Liu, Y., and Moghtaderi, B. (2009). Differences in Reactivity of Pulverised Coal in Air (O2/N2) and Oxy-Fuel (O2/ CO2) Conditions. Fuel Process. Technol. 90, 797-802. doi:10.1016/j.fuproc. 2009.02.009

Roper, F. G., Smith, C., and Cunningham, A. C. (1977). The Prediction of Laminar Jet Diffusion Flame Sizes: Part II. Experimental Verification. Combust. Flame 29, 227-234. doi:10.1016/0010-2180(77)90113-4

Roper, F. G. (1977). The Prediction of Laminar Jet Diffusion Flame Sizes: Part I.Theoretical Model. Combust. Flame. 29, 219-226. doi:10.1016/0010-2180(77) 90112-2

Scheffknecht, G., Al-Makhadmeh, L., Schnell, U., and Maier, J. (2011). Oxy-fuel Coal Combustion-A Review of the Current State-Of-The-Art. Int. J. Greenhouse Gas Control. 5, S16-S35. doi:10.1016/j.ijggc.2011.05.020

Seddighi, S. (2017). Design of Large Scale Oxy-Fuel Fluidized Bed Boilers: Constant thermal Power and Constant Furnace Size Scenarios. Energy 118, 1286-1294. doi:10.1016/j.energy.2016.11.004

Seepana, S., and Jayanti, S. (2012). Experimental Studies of Flame Extinction in a Swirl-Stabilized Oxy-Fuel Burner. Fuel 93, 75-81. doi:10.1016/j.fuel.2011. 10.065

Seepana, S., and Jayanti, S. (2012). Flame Structure Investigations of Oxy-Fuel Combustion. Fuel 93, 52-58. doi:10.1016/j.fuel.2011.07.033

Smith, G. P., Golden, D. M., Frenklach, M., Moriarty, N. W., Eiteneer, B., Goldenberg, M., et al. 2020 Berkeley Mechanical Engineering. Available at: http://www.me.berkeley.edu/gri_mech/.
Taniguchi, M., Yamamoto, K., Okazaki, T., Rehfeldt, S., and Kuhr, C. (2011) Application of Lean Flammability Limit Study and Large Eddy Simulation to Burner Development for an Oxy-Fuel Combustion System. Int. J. Greenhouse Gas Control. 5, S111-S119. doi:10.1016/j.ijggc.2011.05.008

Tu, Y., Liu, H., Chen, S., Liu, Z., Zhao, H., and Zheng, C. (2015). Numerical Study of Combustion Characteristics for Pulverized Coal under Oxy-MILD Operation. Fuel Process. Technol. 135, 80-90. doi:10.1016/j.fuproc.2014. 10.025

$\mathrm{Tu}$, Y., Liu, H., and Yang, W. (2017). Flame Characteristics of CH4/H2 on a Jet-InHot-Coflow Burner Diluted by $\mathrm{N}_{2}, \mathrm{CO}_{2}$, and $\mathrm{H}_{2} \mathrm{O}$. Energy Fuels 31, 3270-3280. doi:10.1021/acs.energyfuels.6b03246

Tu, Y., Su, K., Liu, H., Chen, S., Liu, Z., and Zheng, C. (2016). Physical and Chemical Effects of $\mathrm{CO}_{2}$ Addition on $\mathrm{CH}_{4} / \mathrm{H}_{2}$ Flames on a Jet in Hot Coflow (JHC) Burner. Energy Fuels 30, 1390-1399. doi:10.1021/acs.energyfuels. 5 b02499

Wall, T. F. (2007). Combustion Processes for Carbon Capture. Proc. Combustion Inst. 31, 31-47. doi:10.1016/j.proci.2006.08.123

Wang, J., Matsuno, F., Okuyama, M., Ogami, Y., Kobayashi, H., and Huang, Z. (2013). Flame Front Characteristics of Turbulent Premixed Flames Diluted with $\mathrm{CO}_{2}$ and $\mathrm{H}_{2} \mathrm{O}$ at High Pressure and High Temperature. Proc. Combust. Inst. 34, 1429-1436. doi:10.1016/j.proci.2012.06.154

Watanabe, H., Shanbhogue, S. J., Taamallah, S., Chakroun, N. W., and Ghoniem, A. F. (2016). The Structure of Swirl-Stabilized Turbulent Premixed $\mathrm{CH}_{4} / \mathrm{air}$ and $\mathrm{CH}_{4} / \mathrm{O}_{2} / \mathrm{CO}_{2}$ Flames and Mechanisms of Intense Burning of Oxy-Flames. Combust. Flame. 174, 111-119. doi:10.1016/j.combustflame.2016.09.015

Xie, Y., Wang, J., Zhang, M., Gong, J., Jin, W., and Huang, Z. (2013). Experimental and Numerical Study on Laminar Flame Characteristics of Methane Oxy-Fuel Mixtures Highly Diluted with $\mathrm{CO}_{2}$. Energy Fuels 27, 6231-6237. doi:10.1021/ ef $401220 \mathrm{~h}$

Xu, H., Liu, F., Sun, S., Zhao, Y., Meng, S., and Tang, W. (2017). Effects of $\mathrm{H}_{2} \mathrm{O}$ and $\mathrm{CO}_{2}$ Diluted Oxidizer on the Structure and Shape of Laminar Coflow Syngas Diffusion Flames. Combust. Flame 177, 67-78. doi:10.1016/j.combustflame. 2016.12.001

Yamamoto, K., Ozeki, M., Hayashi, N., and Yamashita, H. (2009). Burning Velocity and $\mathrm{OH}$ Concentration in Premixed Combustion. Proc. Combust. Inst. 32, 1227-1235. doi:10.1016/j.proci.2008.06.077

Yin, C., Rosendahl, L. A., and Kær, S. K. (2011). Chemistry and Radiation in OxyFuel Combustion: A Computational Fluid Dynamics Modeling Study. Fuel 90, 2519-2529. doi:10.1016/j.fuel.2011.03.023

Zhang, Z., Li, X., Luo, C., Zhang, L., Xu, Y., Wu, Y., et al. (2018). Investigation on the Thermodynamic Calculation of a 35 MWth Oxy-Fuel Combustion CoalFired Boiler. Int. J. Green. Gas Control. 71, 36-45. doi:10.1016/j.ijggc.2018. 02.004

Conflict of Interest: The authors declare that the research was conducted in the absence of any commercial or financial relationships that could be construed as a potential conflict of interest.

Publisher's Note: All claims expressed in this article are solely those of the authors and do not necessarily represent those of their affiliated organizations, or those of the publisher, the editors, and the reviewers. Any product that may be evaluated in this article, or claim that may be made by its manufacturer, is not guaranteed or endorsed by the publisher.

Copyright () 2022 Zhang, Li, Xie, Wang and Wang. This is an open-access article distributed under the terms of the Creative Commons Attribution License (CC BY). The use, distribution or reproduction in other forums is permitted, provided the original author(s) and the copyright owner(s) are credited and that the original publication in this journal is cited, in accordance with accepted academic practice. No use, distribution or reproduction is permitted which does not comply with these terms. 